\title{
THE PERSISTENT CONFLICT, A CHARACTERISTIC OF THE CONCEPT OF APPROACHING THE HYBRID WAR IN THE EASTERN EUROPEAN OPERATIONAL ENVIRONMENT
}

\author{
Lt.Col. Valentin PETRESCU, PhD Candidate*
}

\begin{abstract}
The Contemporary Eastern European operational environment is a complex system of actors, weapons and weapon systems, circumstances and conditions that manifest themselves in well-defined areas and that can directly influence decisions to use military capabilities. It may include both enemy and neutral or allied enemy forces and systems participating in the persistent conflict, as well as the culture of the population, the physical environment, local resources, the technological level, the political decision-maker and the executor. The lessons learned from the first part of this century convinced us that the Eastern European operational environment is quite conflictual; constantly changing at local and regional level, it falls into a dynamic, persistent and complex context, which, combined with energy blackmail strategies favor the emergence of hybrid dangers and threats to the stability and security of the Eastern European area. Through this article I want to give a firm and documented answer to questions related to: the conception of approaching the persistent hybrid conflict; the tendency of some actors to persist in tensions in the area of Eastern European insecurity and their concern to maintain the persistent conflict as a form of modern manifestation of Eastern European Community relations.
\end{abstract}

Keywords: operational environment; persistent conflict; hybrid threats; hybrid operating system.

In order to make a coherent analysis, we will start from the hypothesis that state actors present in the conflict environment can fit into a wide range of forces, starting from the structure of a regular force, which belongs to a state, to the level of non-state actors. such as non-governmental or governmental organizations that can act firmly to achieve their own goals. To this scenario, if we add various organized crime and/or terrorist organizations, we have the complete picture that constitutes the operational environment for conducting military operations. In this sense, we can consider that the operational environment extends beyond the geographical theater of conflict, being a military arena in which phase lines and objectives are lost or achieved by using lethal force or by using time in which the fighting force can recover and maintains the security and stability of the conquered objectives. Thus, all actors involved, enemies or allies, non-state or state, regardless of combat capabilities and military capabilities available, will

\footnotetext{
*"Carol I" National Defence University

e-mail:valipetrescu23@yahoo.com
}

use all available tools (military, economic, political and information), in order to achieve the proposed objectives during operation planning.

The theory of US military science defines the main elements that can influence the planning and conduct of military operations specific to the persistent conflict, such as: globalization, demographic change, technological level, resource requirements, urbanization, natural disasters and climate change, proliferation of weapons of mass destruction, failed or poorly governed states, etc. Thus, "the persistent conflict is the prolonged confrontation between state, non-state and individual actors who are willing to use violence to achieve political and ideological goals" ${ }^{\text {. The main }}$ feature of military actions in hybrid operational environments is that combat missions performed with unconventional means may be more numerous and persistent, compared to those performed with conventional means. Often, this aspect derives from the asymmetric configuration of persistent conflicts in the hybrid operating system, which may include components specific to all environments in which military operations can be performed: information environment, physical environment, geophysical environment, moral environment, etc. 


\section{The Eastern European concept of tackling} the persistent hybrid conflict

The concept of approaching hybrid warfare became important in the Eastern European operational environment, it was implemented in the Russian-Ukrainian conflict (2014) and strategically supported by Russian officials. Thus, in his article entitled "The value of science in prediction", General Valery Gherasimov (Chief of the General Staff of the Russian Army) stated on September 1, 2015 that the rules of war will undergo significant changes in its persistence. In this regard, he argues that "the center of gravity of the methods applied in the conflict has shifted towards the widespread use of political, economic, information, humanitarian and other non-military means applied in coordination with the potential protest of the population" 2 . Moreover, he claims that, in the modern conflict environment, asymmetric actions will be present and particularly active, making it possible to reduce the advantages of conventional opponents, present in the theater of operations. Gherasimov emphasizes that an important part of the asymmetric actions will be carried out through the use of special operations forces (FOS) or through close cooperation with internal opposition forces, in order to maintain a persistent conflict situation throughout the territory of enemy troops. These actions will be more effective if they are carried out with improved information and technological means.

Thus, when we talk about the modern conflict, we understand that military officials no longer take into account separate threats, the approaches in this field being fundamentally different. The current doctrine of the Russian army places an important emphasis on the use of new tactics, techniques and procedures for action, combined with simultaneous action. Within the persistent conflict we can observe the trend of convergence of irregular threats, in which the actors in conflict resort to a comprehensive approach in order to achieve strategic objectives. "War is no longer declared, but, once it begins, it is carried out according to an unfamiliar model"3, added the head of the Russian army.

It is necessary to emphasize that there are major differences between the Russian approach strategy, applied, in particular, in Ukraine and the Western strategy. The aspects that differentiate between these types of approaches are related to the fact that, in the Russian conception, conventional threats are missing from the combination. "One of the main objectives pursued by hybrid threats is to destabilize the government and the main institutions of the opponent, thus creating chaos and power vacuum", states Gherasimov. Seeking to gain some strategic advantage and achieve advantageous objectives or alignments, through unexpected tactics and procedures, or by violent means of attack, Russian military theorists have abandoned the use of traditional methods and the predictability of their actions, arguing that this is the sure way to achieve the planned military desideratum.

Moreover, the hybrid threat is invisible, difficult to justify and, consequently, cannot be demonstrated and amended by international legal structures, because state-of-the-art weapon systems, advanced technological means, unexpected tactics and innovative procedures specific to operations are used. In essence, the approach to the new concept of persistent conflict involves a concentrated use of key elements, able to activate the fighting spirit of the great Russian people, these elements being ${ }^{5}$ :

- carrying out actions under the cover of the law - the central element of the Russian military strategy is the creation of perfectly legal aspects, in order to avoid any liability to international legal security bodies. In this regard, a relevant example is the illegal annexation of Crimea by occupying and subsequently simulating a referendum, without international supervision, by which Moscow managed to orchestrate the annexation of the Crimean Peninsula and establish its status, outside the will of the local population and the sovereign state of Ukraine;

- demonstrations of military force - The Russian Army has deployed important military force structures, weapons systems and logistical means near the border with Ukraine, in order to prepare the offensive operation, invade the territory of the neighboring state and forcibly resolve a crisis situation, created at the level of Ukrainian political system;

- the use of the "green men" - Putin's masked ball - in order not to attract international political responsibility, on the territory of Ukraine, the Russian state used special forces from the Vostok battalion (without military insignia), which invaded 
Ukrainian territory as local security, the correct purpose of these operations being to facilitate the intervention of Russian military structures in the area and not to protect the population of Russian nationality;

- using the advantage created by local militias and the screen of tensions in the area - Russia protected its Russian minority population before starting military operations, by supporting and grouping them, providing them with a shield of protection during the intervention;

- propaganda, lies and systematic misinformation - Russia was aware of the importance of the media both nationally and regionally or globally, for which it carried out a vast campaign of manipulation and misinformation of the masses, using several components of the war media that have turned information into a formidable weapon, as follows: humanitarian coverage (motivation of offensive actions with humanitarian arguments, in order to attract consistent support from the international environment); systematic and targeted misinformation in order to activate the fighting spirit of the Russian people (movement used by the Russians and against the Nazi invasion); credible denial - false arguments and bizarre explanations offered by Russian officials about the purposes of the invasion (in support of denying the green men belonging to Russia, Russian officials justified the fact that their uniforms can be bought from any second-hand store); New Russia - motivating aid given to Russian rebels in Ukraine motivated by invoking historical arguments.

In conclusion, the physiognomy of the persistent conflict was perfectly applied in the situation of the invasion of Ukraine (2014), a combination of actions being used simultaneously: political, economic, cyber, psychological and guerrilla, which caused chaos and created vulnerable and destabilized state public authorities.

\section{The physical environment, the environment of using lethal force and resolving persistent conflicts}

The physical environment is the environment of physical spaces, conflicting entities, actions and effects that manifest in the theater of operations. It includes armed groups, military forces, civilians, infrastructure, natural resources, geographical area (air, land and sea), as well as meteorological characteristics (weather, climate, etc.) ${ }^{6}$. By carrying out operations in the physical environment, the aim is to disorganize or prohibit the important activities of the opponent, by using lethal or non-lethal force and by performing maneuvers throughout the area of operations. Most persistent conflicts are resolved in the physical environment, mainly in the area of terrestrial space, as in this environment are placed most of the resources of the participants in the conflict. Usually, resources are most important in the balance of power, as they are the center of gravity of the operations planned in the scheme of the conflict. From here we can conclude that the effect of military actions, carried out in the physical environment, is decisive for destroying the opponent, or for blocking his access to the resources necessary to achieve the planned objectives or achieve the desired alignments / final state.

The military operations carried out in physical space of the persistent conflict have two spatial components (conventional and unconventional), which define the geometry of the operational environment in which the missions planned by the participants in the operation are fulfilled. Wemention the fact that, in the conditions of past conflicts, not very far away, the geometry of the operational space, at operational and tactical level, was quite simplified, it was a geometry of straight lines, which defined contiguous areas. The operational environment of the present persistent conflict is a hybrid one, generated during the development of modern conflicts, with a complicated geometric aspect, in which the conflict areas are concentrated around areas with rich energy resources, or around objectives targeted by hybrid threats. From the perspective of analyzing the disposition of these objectives, using the principles of conventional conflicts, we can understand that it is a chaotic dislocation, in reality, the objectives pursued have a network configuration, and neutralizing an objective can affect the entire structure of the objective network.

The strategy of persistent threats also takes into account the geographical space of the actors in the area that generate the military force, even if the projection of the force and the conduct of operations are performed in an operational theater at a great distance from it. However, the concept of war theater, defined as "land, air and sea space which is or may be directly involved in the conduct 
of major operations or campaigns requiring armed struggle", has become quite complex, given the spatial dimension. of the hybrid operational environment, the strategic objectives pursued and the increased degree of technologizing information and communication systems.

In conclusion, we remain convinced that in any conflict, whether persistent or not, the decisive operation requires the presence and action of the instruments of force, and the maintenance in attention of the specific elements of the geometry of the operational environment is necessary.

\section{The informational environment, the space of manifestation of the forms of persistent confrontation}

The information environment is an environment specialized in carrying out persistent military actions and processes, which performs the procurement, processing and use of data and information, being the link between the moral environment and the physical environment. In essence, this environment is the ideal space for the manifestation of the forms of persistent confrontation which have, as a central and integrating element, the information on the set of measures and actions carried out in order to achieve the objectives pursued. In this environment, non-destructive or destructive actions can be performed.

Persistent non-destructive actions can manifest themselves in order to distort collective or individual perceptions of the situation in the tactical field ${ }^{8}$. The targets of these actions are found either in the spectrum of the military system (interception, espionage, misleading, etc.) or in the spectrum of the civilian community (space of origin or space of deployment of forces), more importantly in the area of decision-making personnel, non-destructive actions can be channeled on psychological actions, providing false information, propaganda, manipulation, etc.

Persistent destructive actions can be carried out permanently, by hitting the structures and means in the composition of the information flow (of the elements in the composition of the commandcontrol system: communication centers, command points, sensors, etc.), or by attacking information technology systems. (communication systems, computer networks, databases, etc.).

The modern information environment, the military structures, has two components: the cybernetic environment and the electromagnetic environment.

The electromagnetic environment is an operational space in which all actions using electromagnetic energy can take place. Usually, these actions precede those performed in moral and physical environments, and the timely and successful accomplishment of some can decisively influence the success of others. Electronic warfare, as a form of persistent conflict, is the sum of offensive and defensive measures that take place directly in the electromagnetic environment, which can be exploited, modeled and used for attack and/ or defence?.

The modern cyber environment encompasses "all systems designed to collect, process and distribute information in support of timely decisionmaking, command and control operations"10, the basic feature of which is that systems have telecommunications networks, integrated processors, computer systems and interdependent computer networks.

From the analysis of the Eastern European insecurity area, it results that the operations carried out in the cyber environment presented several peculiarities. Thus, they aimed at: destroying, banning, disorganizing and delaying the collection, processing and dissemination of information; the use of a wide range of actions specific to the information war (virtual or physical attacks on important information systems of the opponent); entering false or contradictory information into the system; diminishing the fighting power by prohibiting or distorting the opponent's access to the current situation, or by affecting his ability to lead actions; destruction or damage to the architecture of computer systems, information networks, databases and the Internet.

Inconclusion, the Eastern European information environment has, for decision and execution, highperformance information products from its own sources, from related sources with internal, external, judicial responsibility, etc. It encompasses virtually all those information systems and open sources that operate in the environments of interest and facilitates the assurance of information superiority or supremacy, an essential condition for the domination of the battlefield. Through the effects achieved in the space of Russian-Ukrainian forces, it can be concluded that information operations, 
conducted by Russian specialized structures, have exceeded the local borders of the crisis in Ukraine, gaining regional and international proportions.

\section{The moral environment, the environment for carrying out persistent psychological operations}

The moral environment includes "attitudes, beliefs and determinations specific to individuals or groups of individuals, manifested by their desire to overcome fear and aversion and achieve unity of effort, necessary to achieve the proposed goals/ objectives" 11 . The moral environment includes two basic components: the psychological component and the cognitive component. Manifestations of the psychological component are found in the emotional spectrum of the individual, such as: sense of ethnicity, patriotism, faith in which he fights, religious zeal, etc., and the level of education, judgment and issues related to indoctrination we will find in the cognitive component of the human individual.

In essence, operations of persistent conflict that take place in the moral environment aim to influence those behaviors and attitudes of management personnel, commanders, groups, organizations or individuals belonging to allies, partners, own forces, neutrals or adversaries, who manifest themselves vocally to achieve goals and objectives. own forces. The most important types of operations that take place in the moral environment are media operations and psychological operations.

In the psychological operations, carried out in the Eastern European operational environment, the groups of people from the field of action of the armed forces, the civilian population, the morale and the psychic citizen were targeted, using information, images and a specific language, it would hurt their attitude and will. Moreover, these operations had visible effects, targeted volitional, affective and cognitive processes, altered feelings, produced strong emotions and subjected the individual or collective will to the deepest levels of human emotion, in order to weaken psychologically and morally the opponent and cause significant losses.

\section{The geophysical environment, the space} for manifesting threats to the environment

Geophysical warfare was experienced and developed in the latter part of the Cold War, when, in the operational environment, new types of weapons were used, generically called geophysical weapons, with an effect against the environment. In Western literature it was called ecological warfare or meteorological warfare, while in Eastern literature the notion of geoclimatic warfare was used. The persistent conflict specialists claim that there are occult forces that can control the phenomena generated by tornadoes or hurricanes, using them as devastating weapons. They also said that the artificial influence of the weather, as a process of struggle, presented the potential danger of giving rise to uncontrollable destruction, with unforeseen consequences. The worst thing is the high probability that such destruction will have more serious consequences for the population than for the armed forces ${ }^{12}$.

The technique of changing the environment includes a set of techniques to change the structure or composition of the Earth (by deliberate manipulation of natural processes), including outer space, biosphere, hydrosphere, lithosphere and its atmosphere. With the onset of climate change, there has been increasing pressure to develop new technologies that could block the sun's heat or suck carbon dioxide from the atmosphere. Many of the technologies considered can have unpredictable effects, they can get out of control, leading to pandemics with universal action, because they do not respect national borders. Often, critical civil infrastructure has been targeted in regional conflicts, and state and non-state actors have long experience in manipulating the environment for tactical advantage, the implementation of geoengineering technologies being a source of new threats to environmental security.

Collateral damage to the environment was considered an inevitable consequence of armed conflict. At the same time, there were examples of intentional manipulation of the environment by most warring parties, with the environment becoming a weapon of war. There are many examples, some very old, in which the conflicting belligerent forces have deliberately harmed the war environment. Thus, the scorched earth tactic is meant to destroy a certain area and deprive it of any value to opponents, their own troops or civilians. This action may include the destruction of critical civilian infrastructure, food and water sources, shelters, natural resources, etc. The Soviet army 
used this strategy in its withdrawal from Ukraine in World War II in order to slow down the offensive of German troops.

Deliberate deterioration of the environment is a decision caused by a set of natural conditions or dangerous, irresponsible and harmful human activities or serious natural phenomena, with direct effects on the safety and security of the population, both at national and regional level; or global. Among them, we emphasize: natural disasters, severe geophysical or meteorological-climatic phenomena (floods, strong storms, prolonged drought, etc.), generated by global warming; sudden and radical changes in living conditions (landslides, earthquakes, etc.); industrial or ecological catastrophes resulting in heavy loss of life, substantial disruption of economic and social life and serious environmental pollution; the increasing probability of pandemics, the most recent example being the pandemic triggered by the A1H1 virus and Covid-19. These phenomena, in our opinion, give the analyzed factor an accentuated potentially conflicting character which, in the conditions of some unfavorable evolutions, can turn into persistent geophysical war.

Actors who agree with the strategy of persistent conflict often use critical infrastructure to gain a military advantage. This includes the use of environmental infrastructure for strategic purposes, such as some water networks (dams, watercourses, canals and lakes), as well as industrial facilities that are particularly dangerous for the environment. Such use is commonplace, but as societies have become dependent on environmental infrastructure for economic and social life, the consequences of using these arrangements against the warring parties become particularly severe (the reinforcement of water infrastructure provides such an example). Thus, dams, sewage treatment plants, pumping stations or pipelines may be the subject of a deliberate attack to endanger and subjugate the civilian population. The forms of water reinforcement are multiple, from disturbing or diverting watercourses to flooding large areas of land, with serious consequences for both combat forces and the civilian population.

\section{Conclusions}

The analysis of hybrid threats shows that the spatial dimension of the operational environment in which such a persistent conflict takes place extends far beyond the boundaries of the area of operations and even of the theater of operations;

The information operations are, day by day, a category of actions whose role and significance can no longer be neglected in the context of changes in the phenomenon of conflict characteristic of today's society, this trend being imprinted by the role assigned to information that has become a real weapon, embodied in concepts specific to persistent conflict (such as network-based warfare, effectsbased operations, etc.), resulting from the need for effective operations, while limiting the loss of life and destruction of property.

The fact that, during armed conflicts, the environment has been continuously manipulated is not and will not be a surprise. Throughout history, the environment has changed in many ways and for many reasons, from changes in weather to physical changes in natural landscapes. In addition to armed conflict, environmental changes are generally implemented to mitigate environmental risks or improve access to natural resources.

The danger caused by earthquake-type climatic anomalies depends on the proximity of potential sources, their magnitudes and the occurrence rates expressed in probabilistic terms, smaller in magnitude and with short durations.

\section{NOTES:}

1 *** ADRP 3-0, Unified Land Operations, Department of the Army, Washington, 2012, cap. 1, p. 1-1.

2 Valery Gherasimov, General, Chief of the General Staff of Russia, „Valoarea ştiinţei în predicţie” (1 September 2015), Gherasimov Doctrine and Russia's non-linear war on the territory of Ukraine, http://romaniabreakingnews. ro/ doctrina-gherasimov-si-razboiul-non-liniar-dus-de-rusiapeteritoriul-ucrainei/; The value of science in prediction, https://inmoscowsshadows.wordpress.com/2014/07/06/ thegerasimov-doctrine-and-russian-non-linear-war/, accessed on 05.03.2021.

\section{Ibidem.}

4 Ibidem.

5 Rebecca Blum, "The future of NATO in the face of hybrid conflict", Bernard El Ghoul, International Relations, Academic year 2014/2015, p. 5.

6 *** Doctrina Armatei României, Bucharest, 2018, p. 135 .

7 *** JP 1-02, DOD Dictionary of Military Terms, US Department of Defence, Joint Education and Doctrine Division, 2010, https://www.jcs.mil/Portals/36/Documents/ Doctrine/pubs/dictionary.pdf, accessed on 05.03.2021.

8 Ion Bălăceanu, Florian Râpan, Marius Hanganu, Iulian Martin, Doina Mureșan, Valentin Dragomirescu, Interacțiunea strategiilor $\hat{i}$ conflictele armate moderne, 
"Carol I" National Defence University Publishing House, Bucharest, 2010, pp. 49-74.

$9 * * *$ Manualul de planificare a operaţiilor, Bucharest, 2016.

10 *** Doctrina Armatei României, Bucharest, 2018, p. 134.

11 Ibidem, p.135.

12 https://www.hotnews.ro/stiri-arhiva-1258889romania-victima-razboiului-geofizic.htm, accessed on 05.03.2021.

\section{REFERENCES}

*** ADRP 3-0, Unified Land Operations, Department of the Army, Washington, 2012.

*** Doctrina Armatei României, Bucharest, 2018.

*** JP 1-02, DOD Dictionary of Military

Terms, US Department of Defence, Joint Education and Doctrine Division, 2010.
*** Manualul de planificare a operatiilor, Bucharest, 2016.

Bălăceanu Ion, Râpan Florian, Hanganu Marius, Martin Iulian, Mureșan Doina, Dragomirescu Valentin, Interacțiunea strategiilor în conflictele armate moderne, "Carol I" National Defence University Publishing House, Bucharest, 2010.

Blum Rebecca,"The future of NATO in the face of hybrid conflict", Bernard El Ghoul, International Relations, Academic year 2014/2015.

https://www.hotnews.ro

https://inmoscowsshadows.wordpress.com

https://www.jcs.mil/Portals/36/Documents/ Doctrine/pubs/dictionary.pdf

ro/doctrina-gherasimov-si-razboiul-non-liniardus-de-rusiape-teritoriul-ucrainei/

https://inmoscowsshadows.wordpress. com/2014/07/06/the-gerasimov-doctrine-andrussian-non-linear-war/ 